\title{
CHLOROPLASTID PIGMENT CONTENTS AND CHLOROPHYLL $a$ FLUORESCENCE IN AMAZONIAN TROPICAL THREE SPECIES ${ }^{1}$
}

Ronaldo Ribeiro de Morais², José Francisco de Carvalho Gonçalves³, Ulysses Moreira dos Santos Júnior $^{3}$, Oliver Dünisch ${ }^{4}$ e André Luis Wendt dos Santos ${ }^{5}$

\begin{abstract}
Plants react to changes in light and hydrological conditions in terms of quantity and composition of chloroplastidic pigments, which affects the photosynthetic properties and consequently the accumulation of plant biomass. Thus, the chloroplastidic pigment concentration and chlorophyll $a$ fluorescence of three Amazonian species (Bertholletia excelsa, Carapa guianensis e Dipteryx odorata) were investigated in sun and shade leaves form the tree crown collected during two distinct periods of precipitation (dry and rainy seasons). Pigment contents were determined by spectrophotometry and fluorescence variables were determined using a portable fluorometer. The results demonstrated that the species showed high concentrations of $C h l$ $a$, Chl b e Chl total during the wet season in relation to the dry season, especially in shade leaves. A higher concentration of carotenoids was found in B. excelsa, when compared with leaves of C. guianensis and D. odorata. In leaves of $B$. excelsa and $D$. odorata no significant difference was found in relation to the photochemistry of photosystem II $\left(\mathrm{F}_{\mathrm{v}} / \mathrm{F}_{\mathrm{m}}\right)$ between the wet and dry seasons. In conclusion, the three species react differently to variations in the light and precipitation conditions regarding light capture, aspects that might be considered in the management of forest plantations.
\end{abstract}

Keywords: Bertholletia excelsa, Carapa guianensis and Dipteryx odorata.

\section{CONCENTRAÇÃO DE PIGMENTOS CLOROPLASTÍDICOS E FLUORESCÊNCIA DA CLOROFILA a EM ESPÉCIES ARBÓREAS TROPICAIS DA AMAZÔNIA}

\begin{abstract}
RESUMO - As plantas respondem a mudanças nas condições de luz e na disponibilidade hídrica em termos da quantidade e composição dos pigmentos cloroplastídicos, o que afeta as propriedades fotossintéticas e, conseqüentemente, o acúmulo de biomassa das espécies. Assim, a concentração de pigmentos cloroplastídicos e a fluorescência da clorofila a de três espécies arbóreas (Bertholletia excelsa, Carapa guianensis e Dipteryx odorata) da Amazônia foi investigada em folhas sombreadas e não-sombreadas da copa das árvores e em dois períodos distintos de precipitação (chuvoso e seco). As concentrações de pigmentos foram determinadas por espectrofotometria e as variáveis de fluorescência, por meio de um fluorômetro portátil. Os resultados indicaram que as espécies estudadas exibiram maiores concentrações de Chl a, Chl b e Chl ${ }_{\text {total }}$ no período chuvoso, em comparação com o período seco, em especial em folhas de sombra. As maiores concentrações de carotenóides foram observadas em B. excelsa, em comparação com as folhas de C. guianensis e D. odorata.
\end{abstract}

\footnotetext{
${ }^{1}$ Recebido em 21.09.2006 e aceito para publicação em 23.05.2007.

${ }^{2}$ Embrapa, Embrapa Amazônia Ocidental - CPAA, Manaus-AM. E-mail: <biomorais@zipmail.com.br>.

${ }^{3}$ Instituto Nacional de Pesquisas da Amazônia, Manaus-AM. E-mail: <jfc@inpa.gov.br>.

${ }^{4}$ Institute of Wood Biology and Wood Preservation, Harmburg-Germany . E-mail: <oliver_duenisch@gmx.de>.

${ }^{5}$ Centro Universitário Nilton Lins, Laboratório de Biotecnologia Vegetal, Manaus-AM. E-mail: <alwsantos@ yahoo.com.br>.
} 
Nas folhas de B. excelsa e D. odorata, não foram encontradas diferenças significativas em relação à fotoquímica do fotossistema II $\left(F_{v} / F_{m}\right)$, entre os períodos chuvoso e seco. Conclui-se que as três espécies respondem de modo diferente à variação da luz e às condições distintas de precipitação quanto à captura de luz, aspecto que deveria ser considerado no manejo de plantios florestais.

Palavras-chave: Bertholletia excelsa, Carapa guianensis e Dipteryx odorata.

Abbreviations: $\mathrm{Chl} \mathrm{a} / \mathrm{b}$ :(chlorophyll a/b ratio); Chl a (chlorophyll a); Chl b (chlorophyll b); $\mathrm{C}_{\mathrm{x}+\mathrm{c}}$ (carotenoids) $\mathrm{Chl}_{\text {total }} / \mathrm{C}_{\mathrm{x}+\mathrm{c}}$ (chlorophyll total/carotenoids ratio); $\mathrm{F}_{\mathrm{m}}$ (maximum fluorescence); $\mathrm{F}_{\mathrm{o}}$ (initial fluorescence); $\mathrm{F}_{\mathrm{v}}$ (variable fluorescence); $\mathrm{F}_{\mathrm{v}} / \mathrm{F}_{\mathrm{m}}\left(\mathrm{F}_{\mathrm{v}} / \mathrm{F}_{\mathrm{m}}\right.$ fluorescence ratio); PSII (Photosystem II).

\section{INTRODUCTION}

Due to human impact, site conditions in plantations are different from those in primary forests, affecting the growth of the planted trees even when species were used (BAUCH et al., 1999). Comparative studies carried out in primary forests and forest plantations in the Amazon showed significant alterations of light conditions as well as water and nutrient supply (SZOTT and PALM, 1996; NARDOTO and BUSTAMANTE, 2003). Information on growth and demands for light, nutrients, and water of tree species selected for reforestation programs is therefore needed for sustainable timber production (BAUCH et al., 1999). Until the present day, most of the native tree species of the Amazon selected from the primary forest lack information on their physiology and field performance. Photosynthesis is strongly influenced by light intensity and water supply for the plant (DUNISCH and MORAIS, 2002; GONÇALVES et al., 2005). In particular, in plantations established in sites with seasonal climate, a strong spatial and temporal variation in light and hydrological conditions can be expected, which to a certain point explain the differences in plant growth and biomass accumulation between trees grown in plantations and trees grown on natural sites (SCHROTH et al., 2000).

Plants respond to changing light conditions in terms of quantity and composition of pigments in the chloroplasts. At low light intensities, shade leaves have a higher content and a lower ratio of Chlorophyll $a / b$, which is considered to stabilize the light absorbance between photosystem I and II (ALVARENGA et al., 2003; CARVALHO et al., 2006). On the other hand, due to the relationship of chlorophyll $a$ to $b$ in the reaction centre and in the light harvesting complexes (WALTERS, 2005), the ratio of chlorophyll $a$ to chlorophyll $b$ increases at high irradiance (increase of ratio PSII / $\mathrm{Chl}_{\text {total }}$ ).
In addition to light conditions, the water supply modify the electron transport rate and efficiency of light transfer in the antenna during the photosynthesis, which also might have a significant influence on the productivity and biomass allocation in plants (WANG et al., 2006).

The excess of irradiance can drastically decrease the photosynthetic capacity in the plant, contributing to the occurrence of photoinhibition (KITAO et al., 2000). The photoinhibitive process can increase when the excess of irradiance is associated with other factors like water deficiency and high temperatures (LEMOS FILHO, 2000; THOMAS and TURNER, 2001). The photoinhibitive damage is mainly related to changes in the physical-chemical properties of the thylacoidal membranes and electron transport inactivity. These factors cause a reduction in the photochemical quantum yield of PSII, an increase in the dissipation of excess non-photochemical energy, and a decrease in the carboxylation efficiency, which is most likely related to the formation of reactive oxygen species (GILMORE and GOVINDJEE, 1999).

The analysis of chlorophyll $a$ fluorescence is a powerful tool in order to study the conversion, and the transfer of energy in the photosystem II (GONÇALVES et al., 2001; GONÇALVES and SANTOS JUNIOR, 2005; RIBEIRO et al., 2004).

In this study the relationship between the light intensity, precipitation, the concentration of chlorophyll pigments, and the fluorescence of chlorophyll $a$ in the leaves of tree native high value tree species (Bertholletia excelsa, Carapa guianensis, Dipteryx odorata) of the Central Amazon was investigated in order to contribute to a better understanding of physiological aspects of tropical tree species and to the establishment of sustainable production in plantations. 


\section{MATERIALS AND METHODS}

\subsection{Study area and plant species}

The present study was carried out at the experimental site of Embrapa Amazonia Ocidental (Manaus, Amazonas, Brazil), $3^{\circ} 8^{\prime} \mathrm{S}, 5^{\circ} 52^{\prime} \mathrm{W}$, in a polyculture plantation system of approximately 10 years of age. The soil is classified as a poor "Yellow Latosol", developed by tertiary sediments with a reduced capacity for cation exchange. The area is well-drained and a fraction of the clay in the soil is dominated by caolinita. This type of soil is commonly found across large areas of central and eastern Amazon (SCHROTH et al., 2000). According to the Köppen classification, the climate of the region is an Am type, typically tropical with annual average precipitation, temperature and atmospheric humidity of $2500 \mathrm{~mm}, 26$ ${ }^{\circ} \mathrm{C}$ and $85 \%$, respectively. The period of greatest precipitation is found between February and April and the period of least precipitation between July to September (Figure 1). For the determination of the physiological parameters the species Bertholletia excelsa, Carapa guianensis and Dipteryx odorata grown in environmental conditions of the plantations were selected according to their high potential for reforestation programs and timber quality. Leaves fully expanded and showing good health were collected during two distinct precipitation regimes (dry and wet seasons).

\subsection{Pigment analysis}

To determine chloroplastid pigments, six trees per species were randomly chosen and three fully expanded leaves were collected per plant. The data were collected in sun and shade leaves in the months of February 2000 (rainy season) and September 2000 (dry season). We consider as sun leaves, leaves growing in direct sun light, and shade leaves as leaves shaded by others during all day. Leaves were placed between layers of ice in a thermal insulated box and transported to the Plant Physiology and Biochemistry Laboratory (National Institute of Amazon Research), where they were analyzed immediately. Then, samples with $0.1 \mathrm{~g}$ of leaves (fresh material) were grounded in $10 \mathrm{ml}$ of $80 \%$ acetone and $0.5 \%$ (W/V) magnesium carbonate $\left(\mathrm{MgCO}_{3}\right)$ and immediately afterwards 10 $\mathrm{ml}$ of $100 \%$ acetone was added. The suspension was filtered and the absorbance was determined using a spectrophotometer (Jenway 6105 UV/VIS spectrophotometer) with wavelengths at $663 \mathrm{~nm}$ (chlorophyll $a-\mathrm{Chl} a$ ), $645 \mathrm{~nm}$ (chlorophyll $b-$ $\mathrm{Chl} b$ ) and $480 \mathrm{~nm}$ (carotenoids $-\mathrm{C}_{\mathrm{x}+\mathrm{c}}$ ) (ARNON, 1949). Then the values for Chl $a / b$ and $\mathrm{Chl}_{\text {total }} /$ $\mathrm{C}_{\mathrm{x}+\mathrm{c}}$ were evaluated. The calculations for both the mass $\left(\mu \mathrm{mol} \mathrm{g}^{-1}\right)$ and leaf area $\left(\mu \mathrm{mol} \mathrm{m} \mathrm{m}^{-2}\right)$ of the chloroplastid pigments were obtained using the equations of Hendry and Price (1993).

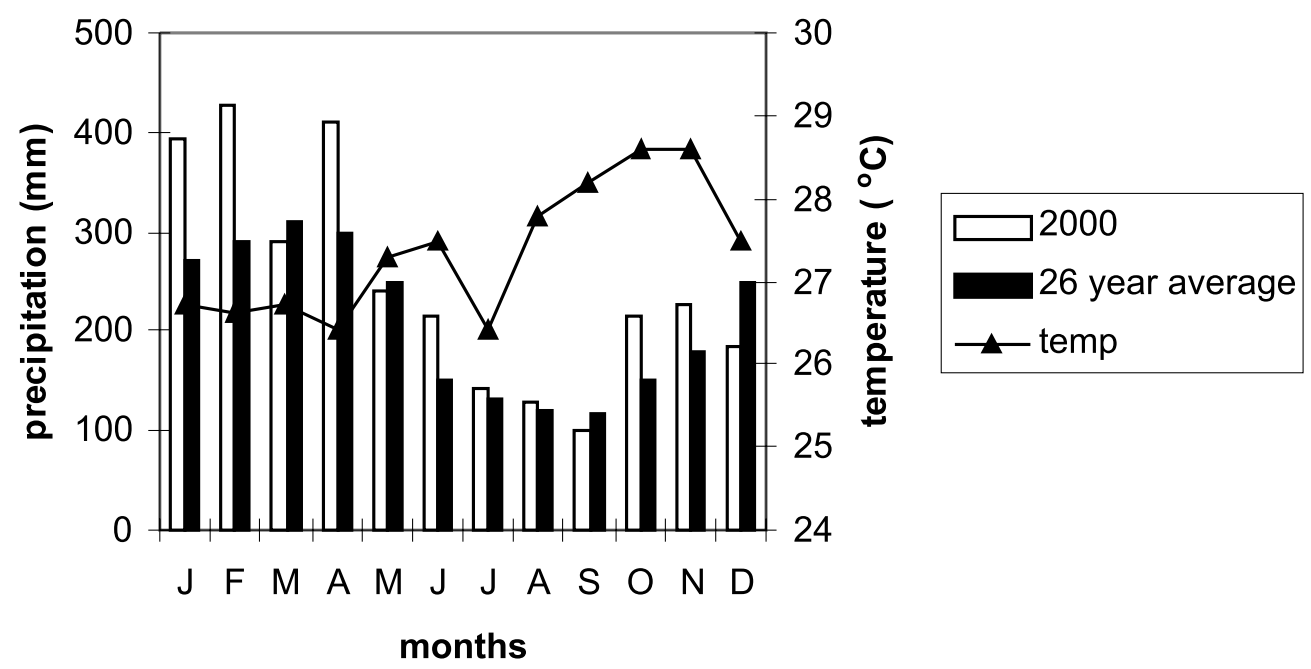

Figure 1 - Average precipitation (mm) between 1970-1995 (mm), monthly temperature $\left({ }^{\circ} \mathrm{C}\right)$ and monthly precipitation during the experimental year (2000) at the experimental site near Manaus (Meteorological data: agrometeorological station of CPAA/Embrapa, Manaus).

Figura 1 - Médias (1970-1995) da precipitação $(\mathrm{mm})$ e temperatura $\left({ }^{\circ} \mathrm{C}\right)$ mensais e precipitação mensal durante o ano do experimento (2000) na área experimental perto de Manaus (dados meteorológicos: estação agrometeorológica do CPAA/Embrapa, Manaus). 


\subsection{Chlorophyll a fluorescence measurements}

The determination of chlorophyll $a$ fluorescence was conducted using a Plant Efficiency Analyzer-MK29600 - Hansatech, Norfolk, UK) in completely expanded leaves of appropriate phytosanitary state according to Gonçalves et al. (2001). The data were collected in sun and shade leaves as described for pigment analysis, in the months of February 2000 (rainy season) and September 2000 (dry season) between 9:00 am and 11:00, three trees per species were randomly chosen and three fully expanded leaves per plant were collected. The selected leaves were subjected to a 30 minutes period of adaptation to darkness, time enough for complete oxidation of the reaction centres. Immediately, the leaves were exposed to a pulse of saturated light at an intensity of $2250 \mu \mathrm{mol} \mathrm{m} \mathrm{m}^{-2} \mathrm{~s}^{-1}$ (75\% of the equipment capacity) and a wavelength of $650 \mathrm{~nm}$. After the induction of fluorescence in fast kinetic the initial fluorescence $\left(\mathrm{F}_{\mathrm{o}}\right)$, the maximum fluorescence $\left(\mathrm{F}_{\mathrm{m}}\right)$, the variable fluorescence $\left(F_{v}=F_{m}-F_{o}\right)$ and the photosynthetic efficiency of PSII $\left(\mathrm{F}_{\mathrm{v}} / \mathrm{F}_{\mathrm{m}}\right)$ were determined.

\subsection{Experimental Design and Statistical Analysis}

The experiment was arranged in completely randomized block with three repetitions in factorial scheme $3 \times 2 \times 2$ with three tree species (B. excelsa, C. guianensis and D. odorata), two precipitation seasons (dry and wet) and two light environments (sunlight and shade). The results were examined by analysis of variance (ANOVA) followed by the Tukey test $(\mathrm{P}=0.05)$, using the software for statistical analyses SAEG (1993).

\section{RESULTS AND DISCUSSION}

During the wet season, a higher chlorophyll contents on a fresh weight basis was found in the leaves (in particular in shade leaves) of all species compared to the drier season (content of Chl $a, \mathrm{Chl} b$ and $\mathrm{Chl}$ total 19-23, 14-25, and 19-24\% higher during the wet season than during the dry season, Figure 2). The chlorophyll content in sun leaves increased $\mathrm{Chl} a, \mathrm{Chl} b$ and $\mathrm{Chl}_{\text {tota }}$ by 54,31 , and $48 \%$ during the wet season compared with the dry season in leaves of D. odorata (Figure 2 ), whereas no significant differences were found in chlorophyll content between the wet and the dry season for Bertholletia and Carapa. However, these results indicate a disorder in the thylakoids membrane under conditions of reduced water availability to the plant (TUBA et al., 1993)

R. Árvore, Viçosa-MG, v.31, n.5, p.959-966, 2007
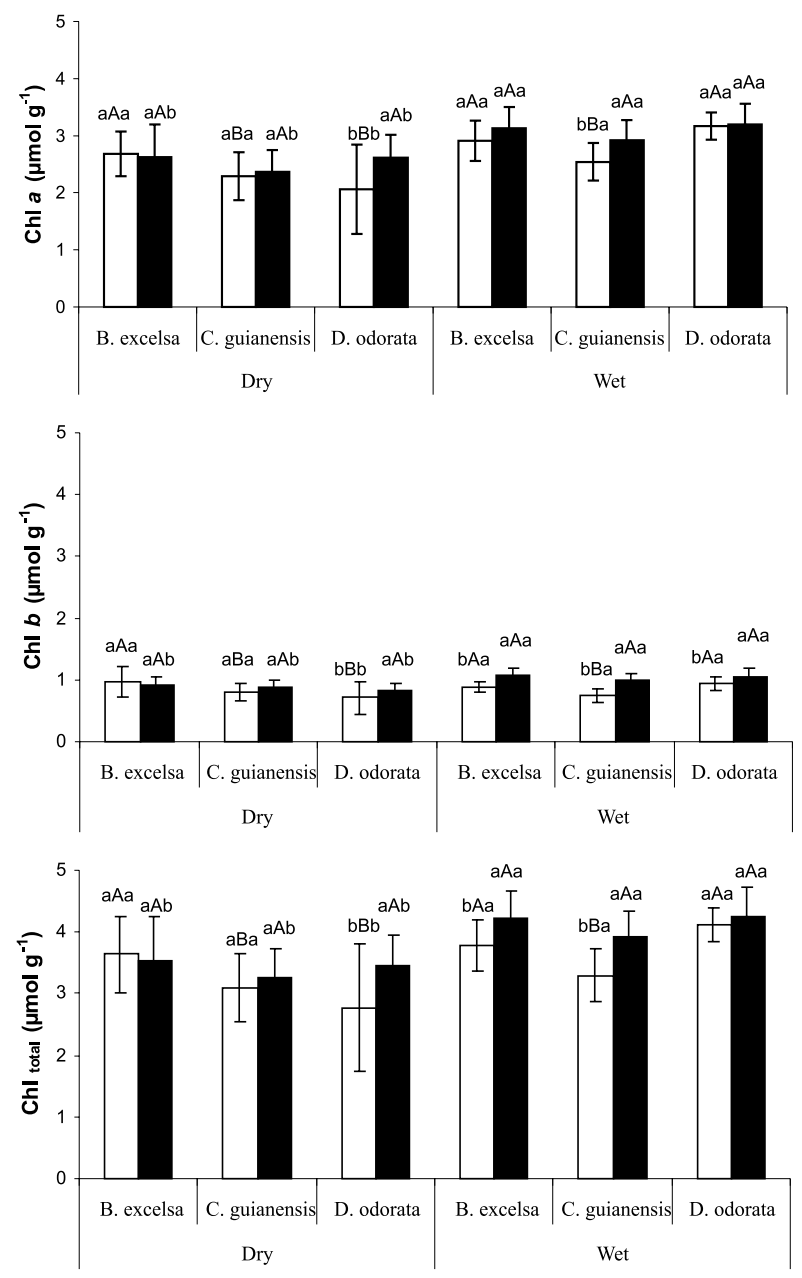

Figure 2 - Concentration of chloroplastidic pigments on leaf mass basis, in different periods of precipitation (Dry and Wet), under different exposures to light, sun leaves $(\square)$ and shade $(\square)$ factorial $3 \times 2 \times 2$. Means followed by the same small letters on the left and right, for different exposures to light and different periods of precipitation, respectively, and by the same capital letter for species, in the same precipitation period, are not significantly different by the Tukey test at $5 \%,(n=18)$.

Figura 2 - Concentração de pigmentos cloroplastídicos na base de massa foliar, em diferentes períodos de precipitação (seco e chuvoso), sob diferentes exposições de luminosidade, folhas de sol ( $\square$ ) e folha de sombra (ם) fatorial $3 \times 2 \times 2$. Médias seguidas pela mesma letra minúscula à esquerda e à direita, em diferentes exposições à luze a diferentes períodos de precipitação, respectivamente, e a mesma letra maiúscula para espécies, num mesmo período de precipitação, não diferem entre si, pelo teste de Tukey a 5\%, $(n=18)$. 
In a similar way, we found higher contents of carotenoids and higher ratios of $\mathrm{Chl} \mathrm{a/b}$ and of $\mathrm{Chl}_{\text {total }}$ / $\mathrm{C}_{\mathrm{x}+\mathrm{c}}$ in leaves harvested during the wetter season compared with leaves harvested during the drier season (Figure 3).

Higher contents of Chl $a, \mathrm{Chl} b$, and Chl were found in shade leaves compared with sun leaves (Figure 2). Because chlorophyll is constantly synthesized and destroyed in the presence of light, but under high light intensity, the rate of decomposition is greater, a balance is established at a lower concentration. For this reason, shaded leaves exhibit higher concentrations of chlorophyll on fresh weight basis than leaves under direct sunlight (TAN et al., 2000). In other words, the chlorophyll content decreased when the levels of irradiance increased (MENDES et al., 2001). Significant differences in the content of $\mathrm{C}_{\mathrm{x}+\mathrm{c}}$ between leaves harvested in the wet season and leaves sampled in the dry season were found in $C$. guianensis and in D. odorata (Figure 3 ).

Beside the strong influence of the water supply on the chlorophyll content of the leaves, we found a significant impact of the light availability on the content of leaves chlorophyll and carotenoids.

Concerning the content of chromatophoric groups, it was recorded in all species a higher ratio of Chl al $b$ in sun leaves compared with shade leaves during the rainy season (Figure 3 ). According to Engel and Poggiani (1991), a greater relative proportion of Chl $b$ in shaded plants is significant because it allows the capture of energy at different wavelengths as well as the transfer of a specific Chl $a$ molecule, which takes part in the photochemical reactions of photosynthesis. Since adaptation to low irradiance can involve an increase in light-harvesting complexes of photosystem II, a decrease of $\mathrm{Chl} a / b$ ratio was expected in shade leaves in comparison with sun leaves. (MENDES et al., 2001).

Unexpectedly, during the drier season, it was observed a higher ratio of Chi $a / b$ in shade leaves of $D$. odorata compared with sun leaves (Figure 3). Due to the little protection of the photosynthetic mechanism, the value of $a / b$ can decrease in leaves exposed to direct sunlight because chlorophyll $a$ has the tendency to degrade faster in conditions of high irradiance than chlorophyll $b$ (ENGEL and POGGIANI, 1991).
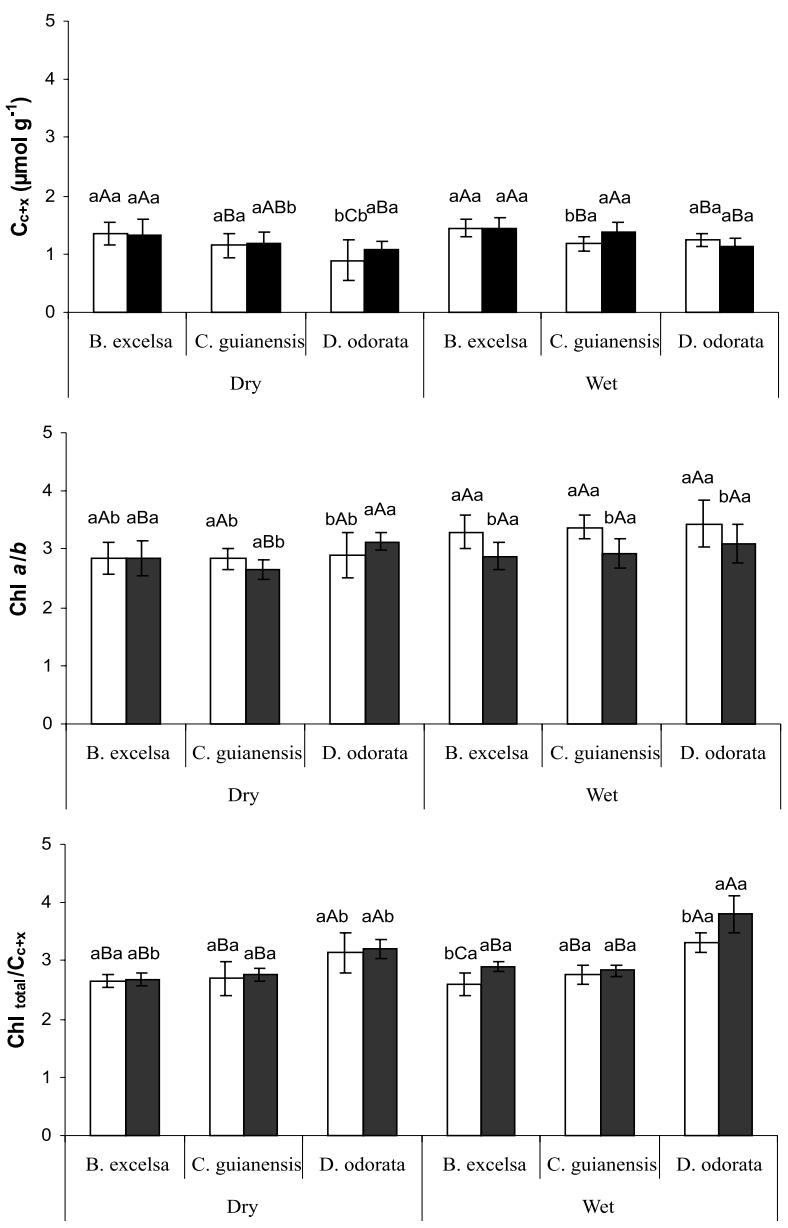

Figure 3 - Concentration of carotenoids, chlorophyll $a / b$ ratio and chlorophyll total/carotenoids ratio on leaf mass basis, in different periods of precipitation (Dry and Wet), under different exposures to light, sun leaves $(\square)$ and shade $(\square)$ factorial $3 \times 2 \times 2$. Means followed by the same small letters on the left and right, for different exposures to light and different periods of precipitation, respectively, and by the same capital letter for species, in the same precipitation period, are not significantly different by the Tukey test to $5 \%,(\mathrm{n}=18)$.

Figura 3 - Concentração de carotenóides, razão clorofila a/b e razão clorofila total/carotenóides na base de massa foliar, em diferentes períodos de precipitação (seco e chuvoso), sob diferentes exposições de luminosidade, folhas de sol $(\square) e$ folha de sombra $(\mathbf{\square})$ fatorial $3 \times 2 \times 2$. Médias seguidas pela mesma letra minúscula à esquerda è à direita, para diferentes exposições à luz e diferentes períodos de precipitação, respectivamente, e a mesma letra maiúscula para espécies, num mesmo período de precipitação, não diferem entre si, pelo teste de Tukey a $5 \%(n=18)$.

R. Árvore, Viçosa-MG, v.31, n.5, p.959-966, 2007 
Changes in the ratios of Chl $a / b$ can be considered as an adaptation to changing light conditions. An increasing ratio of $\mathrm{Chl} a / b$ at high irradiance favors the increase of PSII units and the efficiency of energy conversion (WALTERS, 2005).

During the rainy season a higher ratio of $\mathrm{Chl}_{\text {total }}$ $/ \mathrm{C}_{\mathrm{x}+\mathrm{c}}$ was found in sun leaves of B. excelsa and D. odorata compared with shade leaves (Figure 3 ). This result indicates that in these two species a mechanism for photoprotection is activated (HENDRY and PRICE, 1993).

Significant differences in chlorophyll contents were found between species only in sun leaves. During the drier season the highest contents of Chl $a, \mathrm{Chl}$ $b$, and $\mathrm{Chl}_{\text {total }}$ were found in B. excelsa, whereas the lowest contents were found in leaves of D. odorata. During the rainy season lowest contents were found in the leaves of $C$. guianensis.

The highest content of carotenoids was found in leaves of B. excelsa, indicating a high capacity for
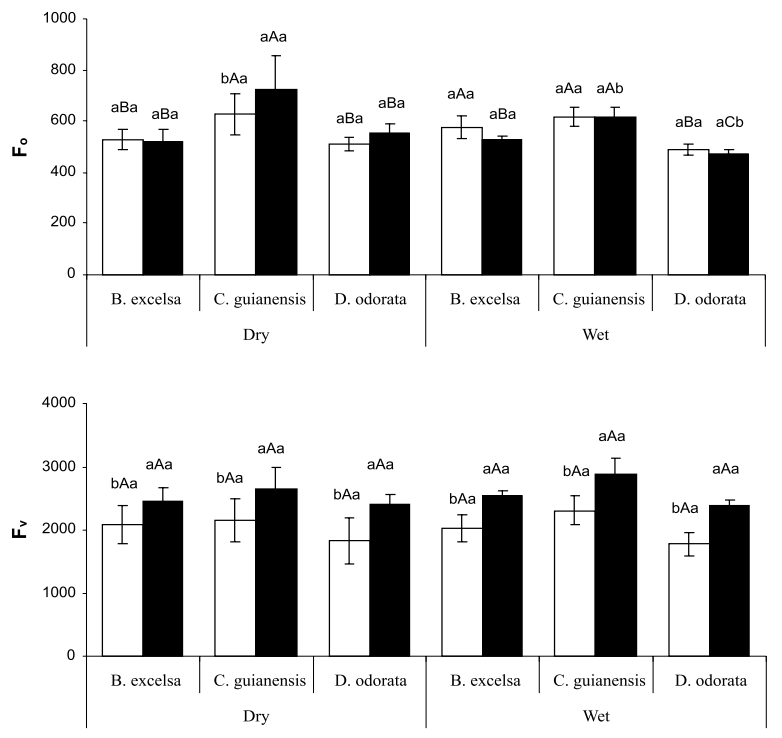

photoprotection in this species. The $\mathrm{Chl} a / b$ ratio in leaves of D. odorata was 10 to $18 \%$ higher compared to leaves of B. excelsa e C. guianensis (shade leaves, drier period, Figure 2). In addition, D. odorata showed the highest ratio of $\mathrm{Chl} \mathrm{total}_{\mathrm{C}+\mathrm{c}} / \mathrm{C}_{\mathrm{c}}$ when compared with the other two species (Figure 3).

The analysis of chlorophyll fluorescence in the leaves showed significant differences of the initial fluorescence $\left(\mathrm{F}_{\mathrm{o}}\right)$ and the photochemical efficiency PSII $\left(\mathrm{F}_{\mathrm{v}} / \mathrm{F}_{\mathrm{m}}\right)$ among the three species (Figure 4). The stable relationship of $\mathrm{F}_{\mathrm{v}} / \mathrm{F}_{\mathrm{m}}$ over time observed in $B$. excelsa and D. odorata gives evidence for the assumption that drier periods had no significant impact on the efficiency of the PSII (BAKER and ROSENQVIST, 2004). Therefore it can be concluded that different assimilation rates observed in these species during the wet and the dry seasons (MORAIS unpublished data) are due to stomata closure and reduced uptake of $\mathrm{CO}_{2}$ during the drier season (BAKER and ROSENQVIST, 2004).
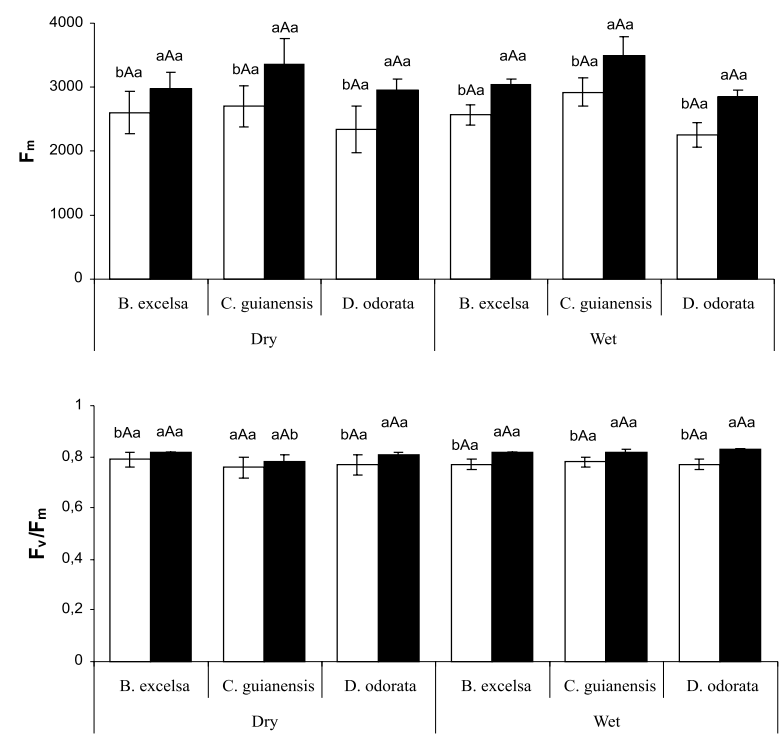

Figure 4 - Fluorescence Variables of chlorophyll a, $F_{o}$ (initial Fluorescence), $F_{m}$ (maximum Fluorescence), Fv (variable Fluorescence) and Fv/Fm (Efficiency of the PS II) of tree species, in different periods of precipitation (Dry and Wet), under different exposures to light, sun leaves $(\square)$ and shade $(\square)$ in the area of Manaus, factorial 3x2x2. Means followed by the same small letters on the left and right, for different exposures to light and different periods of precipitation, respectively, and by the same capital letter for species, in the same precipitation period, are not significantly different by the Tukey test to $5 \%,(\mathrm{n}=9)$.

Figura 4 - Variáveis da fluorescência da clorofila a, $F_{o}$ (fluorescência inicial), $F_{m}$ (fluorescência máxima), $F_{v}$ (fluorescência variável) and $F_{v} / F_{m}$ (eficiência do PS II) de espécies arbóreas, em diferentes períodos de precipitação (seco e chuvoso), sob diferentes exposições de luminosidade, folhas de sol ( $\square$ ) e folha de sombra (ロ) fatorial $3 \times 2 \times 2$. Médias seguidas pela mesma letra minúscula à esquerda e à direita, para diferentes exposições à luz e diferentes períodos de precipitação, respectivamente, e a mesma letra maiúscula para espécies, num mesmo período de precipitação, não diferem entre si, pelo teste de Tukey a $5 \%(n=9)$.

R. Árvore, Viçosa-MG, v.31, n.5, p.959-966, 2007

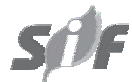


Except for $C$. guianensis, no significant differences in chlorophyll fluorescence $\mathrm{F}_{\mathrm{o}}$ were observed between sun and shade leaves, but highest values of $F_{v}, F_{m}$ and $F_{v} / F_{m}$ were found in shade leaves (Figure 4).

The reduction in the $\mathrm{F}_{\mathrm{v}} / \mathrm{F}_{\mathrm{m}}$ ratio was predominantly due to the reduction of the $\mathrm{F}_{\mathrm{m}}$ value, indicating a reduced efficiency at the transfer of energy, whereas the activity pool of the PSII seems unaffected (KITAO et al., 2000; OLIVEIRA et al., 2002). In addition, the low values for $F_{m}$ in the sun leaves could be associated with the dissipation of energy like heat, which is a strategy that could be used by $D$. odorata when exhibiting low values for $\mathrm{F}_{\mathrm{m}}$ (GONÇALVES et al., 2001). The very low differences of the $\mathrm{F}_{\mathrm{v}} / \mathrm{F}_{\mathrm{m}}$ values (4-8\%) measured under changing light and hydrological conditions indicate a good physiological adaptation of the three species to a reduced light availability and water supply.

\section{CONCLUSION}

In spite of the seasonal variation in the content of photoactive pigments in the leaves of these species, the results indicate that the environmental conditions of the plantations did not significantly compromise the performance of the photosynthetic mechanism, even in the period of low precipitation in the region, thus confirming that the species studied were not subjected to stress. The species considered in this study had different strategies to capture light energy, both incidental and diffuse. Therefore, the present work concludes that these ecophysiological differences among species might be considered for the establishment of productive, sustainable and management of forest plantation systems.

\section{REFERENCES}

ALVARENGA, A. A. et al. Effects of different light levels on the initial growth and photosynthesis of Croton urucurana Baill. in southeastern Brazil. Revista Árvore, v.27, n.1, p.53-57, 2003.

ARNON, D. I. Copper enzymes in isolated chloroplast polyphenol oxidase in Beta vulgaris. Plant Physiology, n.52, p.257-262, 1949.

BAKER, N. R.; ROSENQVIST, E. Applications of chlorophyll fluorescence can improve crop production strategies: an examination of future possibilities. Journal of Experimental Botany, v.55, n.403, p.1607-1621, 2004.
BAUCH, J.; DÜNISCH, O.; GASPAROTTO, L. Investigations on tree species suitable for the recultivation of degraded land areas in central Amazon. Mitteilungen der Bundesforschungsanstalt für Forstund Holzwirtschaft, n.193, p.1-29, 1999.

CARVAlHO, N. O. S. et al. Crescimento inicial de plantas de licuri (Syagrus coronata (Mart.) Becc.) em diferentes níveis de luminosidade. Revista Árvore, v.30, n.3, p.351-357, 2006.

DUNISCH, O.; MORAIS, R. R. Regulation of xylem sap flow in an evergreen, a semi-deciduos, and a deciduos Meliaceae species from the Amazon. Trees, n. 16, p.404-416, 2002.

ENGEL, V. L.; POGGIANI, F. Estudo da concentração de clorofila nas folhas e seu espectro de absorção de luz em função do sombreamento em mudas de quatro espécies florestais nativas. Brazilian Journal of Plant Physiology, v.3, n.1, p.39-45, 1991.

GILMORE, A. M.; GOVINDJEE, G. How plants respond to excess light: energy dissipation in photosystem II. In: SINGHAL, G. et al. (Eds) Concepts in photobiology: photosynthesis and photomorphogenesis, Narosa Pub., Índia: 1999.

GONÇALVES, J. F. C.; MARENCO, R. A.; VIEIRA, G. Concentration of photosynthetic pigments and chlorophyll fluorescence of mahogany and tonka bean under two light environments. Brazilian Journal of Plant Physiology, v.13, n.2, p.149-157, 2001.

GONÇALVES, J.F.C. et al. Growth, photosynthesis and stress indicators in young rosewood plants (Aniba rosaeodora Ducke) under different light intensities. Brazilian Journal of Plant Physiology, v. 17, n.3, p.325-334, 2005.

GONÇALVES, J. F. C.; SANTOS JÚNIOR, U. M. Utilization of the chlorophyll $a$ fluorescence technique as a tool for selecting tolerant species to environments of high irradiance. Brazilian Journal of Plant Physiology, v.17, n.3, p.307-313, 2005.

R. Árvore, Viçosa-MG, v.31, n.5, p.959-966, 2007 
HENDRY, G. A. F.; PRICE, A. H. Stress indicators: chlorophylls and carotenoids. In: HENDRY, G. A. F.; GRIME, J. P. (Eds), Methods in comparative plant ecology. London: Chapman \& Hall, 1993. p.148-152.

KITAO, M. et al. Temperature response and photoinhibition investigated by chlorophyll fluorescence measurements for four distinct species of dipterocarp trees. Physiologia Plantarum, n.109, p.284-290, 2000.

LEMOS FILHO, J. P. Fotoinibição em três espécies do cerrado (Annona crassifolia, Eugenia dysenterica e Campomanesia adamantium) na estação seca e chuvosa. Revista Brasileira de Botânica, v.23, n.1, p.45-50, 2000.

MENDES, M. M.; GAZARINI, L. C.; RODRIGUES, M. L. Acclimation of Myrtus communis to contrasting Mediterranean light environments effects on structure and chemical composition of foliage and plant water relations.

Environmental and Experimental Botany, n.45, p.165-178, 2001.

NARDOTO, G. B.; BUSTAMANTE, M. M. C. Efeitos do fogo na dinâmica do nitrogênio no solo e biomassa microbiana em área de Cerrado.

Pesquisa Agropecuária Brasileira, v.38, n.8, p.955-962, 2003.

OLIVEIRA, J. G.; ALVES, P. L. C. A.; MAGALHÃES, A. C. The effect of chilling on the photosynthetic activity in coffe (Coffea arabica L.) seedlings. The protective action of chloroplastid pigments. Brazilian Journal of Plant Physiology, v.14, n.2, p.95-104, 2002.

RIBEIRO, R.V. et al. Chlorophyll fluorescence of tropical tree species in a semi-deciduous forest gap. Revista Árvore, v.28, n.1, p.21-27, 2004.
SAEG Sistemas para Análises Estatísticas, Versão 5.0. Viçosa, MG: Fundação Arthur Bernades -Universidade Federal de viçosa, 1993.

SCHROTH, G. et al. Nutrient concentrations and acidity in ferralitic soil under perennial cropping, fallow and primary forest in Central Amazonia.

European Journal of Soil Science, n.51, p.219-231, 2000.

SZOTT, L.; PALM, C. Nutrient stocks in managed and natural humid tropical fallows. Plant and Soil, n.186, p.293-309, 1996.

TAN, Y. et al. Resolution of kinetic system of simultaneous degradation of chlorophyll $a$ and $b$ by Parafac. Analytical Chemistry Acta, n.412, p.195-202, 2000.

THOMAS, D. S.; TURNER, D. W. Banana (Musa sp.) leaf gas exchange and chlorophyll fluorescence in response to soil drought, shading and lamina folding. Scientia Horticulturae, n.90, p.93-108, 2001.

TUBA, Z. et al. Resynthesis of thylakoids and functional chloroplasts in the desiccated leaves of the poikilochlorophyllous plant Xerophyta scabrida upon rehydration. Journal of Plant Physiology, n.142, p.742-748, 1993.

WALTERS, R. G. Towards an understanding of photosynthetic acclimation. Journal of Experimental Botany, v.56, n.411, p.435-447,2005.

WANG, G. G.; BAUERLE, W. L.; MUDDER, B. T. Effects of light acclimation on the photosynthesis, growth, and biomass allocation in American chestnut (Castanea dentata) seedlings. Forest Ecology and Management, v. 226, p.173-180, 2006. 